\title{
Effect of Operating Variables on DMFC Performance for the Synthesized Si-PWA/PVA Nanocomposite Membrane
}

\author{
Jay Pandey*
}

\author{
Department of Chemical Engineering, Indian Institute of Technology Delhi, Hauz Khas, New Delhi-110016, \\ India
}

\begin{abstract}
Electrochemical Performance of DMFC was studied under the effect of various operating parameters like temperature, methanol concentration and relative humidity $(\mathrm{RH})$ for the synthesized silica immobilized phosphotungstic acid-poly(vinyl alcohol) (Si-PWA/PVA) nanocomposite membrane (thickness 80-100 $\mu \mathrm{m}$ ). The optimized $1.5 \mathrm{Si}$ PWA/PVA membrane showed good electrochemical properties (transport number: 0.92 and IEC: 0.90 meq/g) with excellent mechanical strength, thermal and chemical stability. Open circuit voltage (OCV) decay was significantly lower in comparison to Nafion-117. Maximum power density $\left(45.7 \mathrm{mWcm}^{-2}\right)$ was obtained at $60^{\circ} \mathrm{C}$ cell temperature. DMFC performance exhibited better performance even at higher methanol concentration (2 $\mathrm{M})$ demonstrating lower concentration over potential. The appreciable rise in the peak power density observed at higher relative humidity $(90 \%)$ showed good water stability of the membrane. Performance of the DMFC with the synthesized composite membrane was comparable to the state of the art Nafion-117.
\end{abstract}

Keywords: Nanocomposite membrane, Membrane electrode assembly, proton conductivity, methanol crossover, over-potential.

\section{INTRODUCTION}

Due to increasing concern over depleting energy resources, focus on renewable energy devices, like fuel cells, supercapacitors and flow batteries, has garnered much popularity due to their eco-friendly features as well as cost-effectiveness [1]. Amongst all, the direct methanol fuel cell (DMFC) device is highly preferred due to its high efficiency (60\%), zero emission and easy in operation. However, in real applications DMFC suffers from various problems like fuel crossover, higher internal cell resistance, water management and poor long term durability which are hampering worldwide commercialization of DMFC technology [2].

The major hurdle is higher cell overpotential at different cell components like at electrodes and solid electrolytic membrane. Therefore it is imperative to minimize the cell overpotential by optimizing the process variables like temperature, methanol concentration, and relative humidity. It was observed that the small changes in operating conditions have great influence on the cell overpotential and thereby drastic change in DMFC performance. For instance, increasing temperature drastically increases electrode kinetics thereby lowering the activation overpotential as well CO-poisoning of the catalyst. High methanol concentration in the fuel improves the rate of reaction by minimizing the concentration overpotential and the

*Address correspondence to this author at the Department of Chemical Engineering, Indian Institute of Technology Delhi, Hauz Khas, New Delhi110016, India; Tel: +91 9718251235; E-mail: jay.pandey.iitd@gmail.com optimum relative humidity is important for membrane to be in fully hydrated state which provides easy proton conduction and lowering the ohmic overpotential [3].

However, in the most of cases, change in the one of the DMFCs operating parameters leads to the adverse effects on the DMFC performance due to secondary effects. For instance, increasing temperature leads to dehydration of the membrane and increases the internal cell resistance. High methanol concentration leads to the higher methanol crossover to cathode side causing mixed potential and lowering open circuit voltage (OCV) of the cell [4]. High humidity at cathode side causes the back diffusion of water causing mechanical instability and water flooding. Therefore the proper optimization of all the operating parameters is very crucial for the better DMFC performance [5].

In past, there are several reports describing effect of operating parameters on DMFC performance particularly for Nafion based membrane however, very little works are reported on the detailed discussion on affecting parameters for the inorganic-organic hybrid membranes due to their poor long term durability. Chen et al. [6] have reported the optimum cell performance at $60{ }^{\circ} \mathrm{C}$ cell temperature and $2 \mathrm{M}$ methanol concentration for Nafion-117 membrane. Surampidi et al. [7] measured the DMFC performance at $30,60,90^{\circ} \mathrm{C}$ and demonstrated improvement in performance with increase in temperature attributed to lower activation overpotential at elevated temperature. Yu et al. [8] have reported a CFD model with semi-empirical electrochemical relationship to study the influence of 
geometric an operating parameters on DMFC performance for Nafion-117 membrane. DMFC current density was enhanced from $60 \mathrm{~mA} / \mathrm{cm}^{2}$ to $90 \mathrm{~mA} / \mathrm{cm}^{2}$ on increasing temperature from 50 to $70^{\circ} \mathrm{C}$. On the other hand with increase in methanol concentration from 0.25 to $0.5 \mathrm{M}$, the current density was found to be improved from 70 to $80 \mathrm{~mA} / \mathrm{cm}^{2}$ however, further increase in methanol concentration up to $1 \mathrm{M}$ resulted into drop in current density which was ascribed to methanol crossover through the Nafion membrane at this concentration. Oliveira et al. [9] measured the DMFC performance for Nafion-117 membrane at room temperature and $60 \%$ relative humidity and described that the poor power density and low cell efficiency are caused by higher methanol crossover and sluggish electrochemical oxidation of methanol at anode catalysts.

In our previous work, we reported the detailed synthesis protocol, physico-chemical and electrochemical characterization of inorganic-organic Si-PWA/PVA ion-exchange membrane and tested the membrane's electrochemical performance in single cell DMFC $\left(25 \mathrm{~cm}^{2}\right)$ at ambient condition $\left(25^{\circ} \mathrm{C}\right.$ and $60 \%$ $\mathrm{RH}$ ) and it was observed that the DMFC performance was comparable to state of the art Nafion-117 [10]. Herein, we present the detailed DMFC studies and influence of process variables (temperature, methanol concentration and relative humidity) on the electrochemical performance (proton conductivity and methanol crossover) of DMFC for the synthesized SiPWA/PVA membrane. Before the DMFC runs the membrane electrode assembly (MEA) was fabricated by keeping the catalyst loading of $2 \mathrm{mg} / \mathrm{cm}^{2}$ each for anode $(\mathrm{Pt}-\mathrm{Ru} / \mathrm{C})$ and cathode $(\mathrm{Pt} / \mathrm{C})$ electrodes. The performance of the DMFC with the composite membrane was also compared with the state of the art Nafion-117 membrane.

\section{EXPERIMENTAL}

\section{Membrane Synthesis and Characterization}

Si-PWA/PVA membrane was synthesized by physical blending of sub-micron sized Si-PWA ionexchanger and crosslinked PVA solution followed by solution casting method as reported in our previous work [10]. The synthesized membrane was further characterized using various physico-chemical characterization techniques using FT-IR, XRD, SEMEDS, stability test and methanol crossover [10]. Herein, we measured the electrochemical properties like transport number and ion-exchange capacity (IEC) for confirmation of good ion-transport and ion-exchange properties of the synthesized membranes. For this loading of Si-PWA in crosslinked PVA solution was varied from 0.5 to 1.5 by varying the was molar ratio of PWA and silica. The IEC and transport no. was then measured to observe the effect of Si-PWA loading into PVA. Additionally, to confirm the suitability of synthesized membrane in DMFC, all the detailed studies were performed only for optimized Si-PWA loading in PVA.

\section{Membrane Electrode Assembly (MEA) Fabrication}

MEA was prepared by the hot pressing, at $60^{\circ} \mathrm{C}$ temperature and $10 \mathrm{MPa}\left(100 \mathrm{Kgcm}^{-2}\right)$ pressure for 5 min, the optimized Si-PWA/PVA membrane between two commercially available (Johnson Matthey catalysts, Alfa Aesar India Ltd., Hyderabad) anode (Pt-Ru/C) and cathode catalyst $(\mathrm{Pt} / \mathrm{C})$. Anode and cathode catalyst loading was $2 \mathrm{mgcm}^{-2}$ same for both. Figure 1 illustrates the photograph of synthesized MEA for single cell DMFC test.

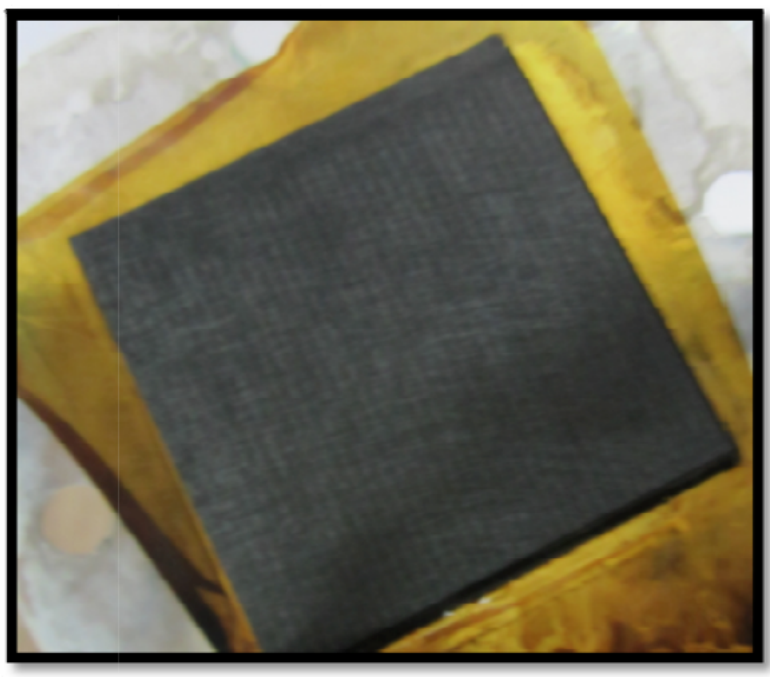

Figure 1: In-house fabricated membrane electrode assembly (MEA).

\section{Proton Conductivity and Methanol Crossover Test}

Proton conductivity of the synthesized membrane at $30^{\circ} \mathrm{C}$ was calculated from measured values of resistance using two-compartment cell with and without membrane was measured on a Potentiostat/ Galvanostat with frequency response analyzer (FRA) (make: Gamry, model: Reference-600). First the membrane was equilibrated with $0.5 \mathrm{M} \mathrm{HCl}$ solution for $12 \mathrm{~h}$ before measurement. Both the compartments were filled with $0.5 \mathrm{M}$ solution of $\mathrm{HCl}$. Impedance value, measured at $1000-1 \mathrm{MHz}$, at zero phase angle was 
taken as the resistance of the cell. Membrane resistance $(\mathrm{Rm})$ was obtained from difference of resistance values of cell, with and without membrane. Membrane resistance was measured at different temperature between 30 and $60^{\circ} \mathrm{C}$ under ambient relative humidity $(60 \%)$.

The proton conductivity of the synthesized membrane under different relative humidity (40 to $90 \%$ ) was also measured by exposing the synthesized membranes at room temperature under different saturated salts of different relative humidity for $24 \mathrm{~h}$ followed by impedance measurements.

A two-compartment diffusion cell was used to measure the permeation of methanol through synthesized membrane. Both compartments of capacity of $20 \mathrm{~cm}^{3}$ each had provision for stirring. Before the experiment, the membrane was equilibrated in de-ionized water for $12 \mathrm{~h}$. Initially, one compartment (A) contained an aqueous solution of methanol (1 M) while the other $(B)$ contained de-ionized water. Liquids in both the compartment were continuously stirred during the experiments in order to maintain uniform concentration throughout the compartment. The concentration of methanol in compartment B was determined at different times using a gas chromatography (Make: Nucon Gas Chromatograph, Model: 5765) equipped with flame ion detector (FID). Methanol permeability $(\mathrm{P})$ was calculated by the below given formula reported in literature [10].

\section{OCV Decay Test}

OCV decay test for single cell DMFC was conducted for $2 \mathrm{~h}$ at $35^{\circ} \mathrm{C}, 2 \mathrm{M}$ methanol concentration of flow rate $3 \mathrm{mlmin}^{-1}$ with air flow rate of $300 \mathrm{mlmin}^{-1}$ under $60 \%$ relative humidity.

\section{DMFC Performance under Operating Variables}

Polarization and power density curves were collected on a $25 \mathrm{~cm}^{2}$ DMFC single cell (Electrochem Inc. USA). The detailed experimental specifications for single cell DMFC run are given in Table $\mathbf{1}$ and Figure 2 shows the schematic of experimental set-up of single cell DMFC. The base case value of variables was $1 \mathrm{M}$ methanol flow rate of $3 \mathrm{mlmin}^{-1}$ on anode side and $60 \%$ relative humidity air flow rate of $300 \mathrm{mlmin}^{-1}$ on cathode side, and $35^{\circ} \mathrm{C}$ temperature. The DMFC performance was also analyzed at different operating conditions like temperature, methanol concentration and relative humidity. DMFC polarization and power density curves were obtained by independently varying temperature, relative humidity of air and concentration of methanol and the values of these variables are given in Table 2 .

Table 1: Experimental Specifications for Single Cell DMFC

\begin{tabular}{|c|c|}
\hline Parameters & Value \\
\hline \hline Solid electrolyte (membrane) & Si-PWA/PVA \\
\hline Effective MEA area & $25 \mathrm{~cm}^{2}$ \\
\hline Anode catalyst & $2 \mathrm{mg} / \mathrm{cm}^{2}(\mathrm{Pt}-\mathrm{Ru} / \mathrm{C})$ \\
\hline Anode backing layer (ABL) thickness & $220 \mu \mathrm{m}$ \\
\hline Anode catalyst layer (ACL) thickness & $10 \mu \mathrm{m}$ \\
\hline Thickness of membrane & $100 \mu \mathrm{m}$ \\
\hline Cathode catalyst & $2 \mathrm{mg} / \mathrm{cm}^{2}(\mathrm{Pt} / \mathrm{C})$ \\
\hline Cathode backing layer (CBL) thickness & $220 \mu \mathrm{m}$ \\
\hline Cathode catalyst layer (CCL) thickness & $10 \mu \mathrm{m}$ \\
\hline Area of current collector & $100 \mathrm{~cm}^{2}$ \\
\hline
\end{tabular}

\section{RESULTS AND DISCUSSION}

Here, we analyzed the single cell DMFC performance like OCV decay test, effect of different operating variables like temperature, methanol concentration and relative humidity for the optimized Si-PWA/PVA membrane in detailed. In addition the effect of temperature, \% relative humidity on proton conductivity and effect of methanol concentration on the methanol crossover of the synthesized membrane was also carried out.

\section{IEC and Transport No.}

Figure 3 shows the effect of Si-PWA loading in PVA on IEC and transport no. of the synthesized membranes and it was found that initially with increase in the Si-PWA loading in PVA led to increase in both IEC and transport no. due to increase in the fixed charge concentration of the ion-exchanger in the membrane. However, further increase in the loading led to drop in IEC and transport no. due to agglomeration of Si-PWA causing blockage in ionconducting sites on the membrane surface. Measured IEC and transport no. of the synthesized membranes exhibited that the $1.5 \mathrm{Si}$-PWA/PVA membrane has good ion-transport properties (transport no.: 0.92) and ion-exchange capacity $(0.9 \mathrm{meq} / \mathrm{g})$ which confirmed that this composition can be utilized as solid electrolytic membrane in DMFC. 


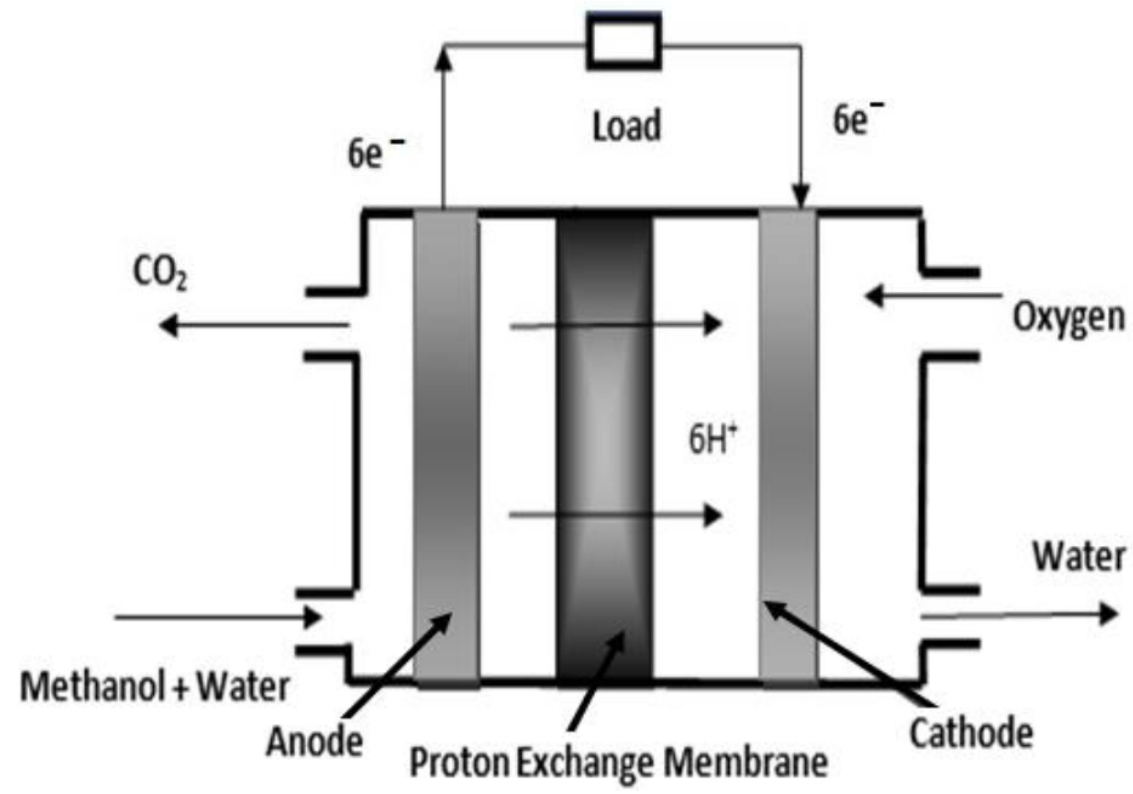

Figure 2: Experimental set-up for single cell DMFC.

Table 2: Experimental Conditions for Single Cell DMFC Run

\begin{tabular}{|c|c|}
\hline Parameter & Range \\
\hline \hline Pressure & 1 bar \\
\hline Temperature & $30,40,60^{\circ} \mathrm{C}$ \\
\hline Methanol concentration & $0.5,1,2 \mathrm{M}$ \\
\hline Relative humidity & $40,60,90 \%$ \\
\hline Anode flow rate & $3 \mathrm{ml} / \mathrm{min}$ \\
\hline Cathode flow rate & $300 \mathrm{~cm}^{3} / \mathrm{min}$ \\
\hline
\end{tabular}

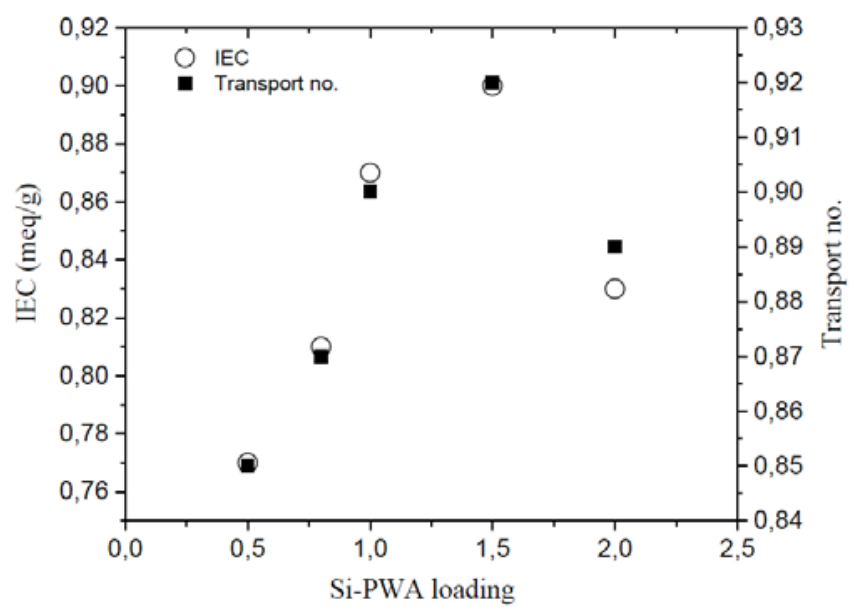

Figure 3: Effect of Si-PWA loading on IEC and transport no. of the synthesized membranes.

\section{OCV Decay Test}

Figure 4 shows the OCV decay of the synthesized membrane and Nafion- 117 measured at $35^{\circ} \mathrm{C}$. For the synthesized membrane the maximum achieved OCV was $0.815 \mathrm{~V}$ and dropped to $0.8 \mathrm{~V}$, on the other hand for Nafion-117 the OCV dropped from $0.695 \mathrm{~V}$ to 0.665 V. \% OCV decay was $1.84 \%$ much lower compared to Nafion-117 which showed $4.31 \%$ OCV decay. The lower OCV decay compared do Nafion-117 was due to lower methanol crossover of the synthesized $1.5 \mathrm{Si}$ PWA/PVDF membrane as reported in our previous publication [10]. The results showed that the synthesized $1.5 \mathrm{Si}$-PWA/PVA membrane has good long term durability in DMFC conditions.

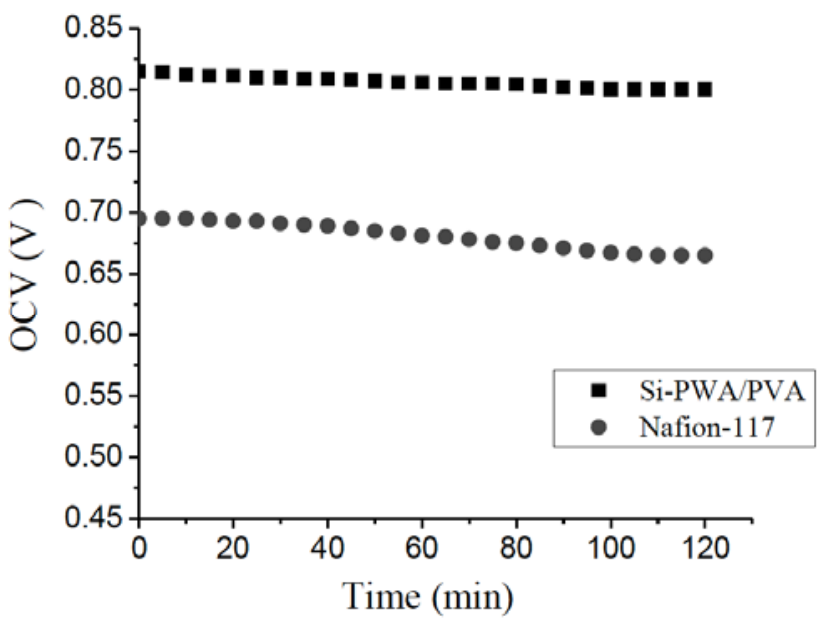

Figure 4: OCV decay of the synthesized membrane and Nafion-117.

\section{Effect of Operating Parameters on DMFC Performance}

Effect of temperature, methanol concentration and relative humidity on DMFC performance was 
determined by varying one of these operating parameters.

\section{Effect of Temperature}

Before studying the DMFC performance with temperature, the effect of temperature on the proton conductivity of the membrane was measured under ambient relative humidity $(60 \%)$ as shown in Figure 5 a. It was found that the proton conductivity increased from $7.04 \mathrm{mScm}^{-1}$ to $12.3 \mathrm{mScm}^{-1}$ upon elevating the temperature from 30 to $60^{\circ} \mathrm{C}$. The enhanced proton conductivity at elevated temperature $\left(60^{\circ} \mathrm{C}\right)$ was ascribed to fast proton activity and reducing the ohmic resistance through the membrane [11].

Temperature was varied from $30^{\circ} \mathrm{C}$ to $60^{\circ} \mathrm{C}$ keeping the methanol concentration fixed at $1 \mathrm{M}$ with $60 \%$ relative humidity of air. Figure $\mathbf{5 b}$ shows the performance of DMFC for the 1.5 Si-PWA/PVA membrane at different temperatures $\left(30\right.$ to $\left.60^{\circ} \mathrm{C}\right)$. OCV increased from $0.805 \mathrm{~V}$ to $0.885 \mathrm{~V}$, with increase in temperature from $30^{\circ} \mathrm{C}$ to $60^{\circ} \mathrm{C}$ due to enhanced electrode kinetics at higher temperature [12]. Peak power density at $60^{\circ} \mathrm{C}\left(45.7 \mathrm{mWcm}^{-2}\right.$ at the cell voltage of $0.532 \mathrm{~V}$ ) was much higher compared to the value at $30^{\circ} \mathrm{C}\left(23.2 \mathrm{mWcm}^{-2}\right.$ at cell voltage of $\left.0.465 \mathrm{~V}\right)$. The maximum achieved current density was $70 \mathrm{mAcm}^{-2}$ at $30^{\circ} \mathrm{C}$ and it increased to $107 \mathrm{mAcm}^{-2}$ at $60^{\circ} \mathrm{C}$. The improved power density at elevated temperature $\left(60^{\circ} \mathrm{C}\right)$ was attributed to lower internal resistance and ohmic opverpotential owing to higher proton conductivity (12.3 $\mathrm{mScm}^{-1}$ ) as mentioned above.

\section{Effect of Methanol Concentration}

To analyze the effect of methanol concentration on the methanol crossover of the synthesized $1.5 \mathrm{Si}$ PWA/PVA membrane, the methanol crossover was measured at different methanol concentration ( 0.5 to 2 $\mathrm{M})$ and it was observed that there was slight increase in the crossover on increasing the concentration from 0.5 to $1 \mathrm{M}$ as shown in Figure $6 \mathrm{a}$, however further change in methanol concentration from 1 to $2 \mathrm{M}$ there was very minimal change in methanol crossover which demonstrates the poor methanol selectivity of the synthesized 1.5 Si-PWA/PVA membrane [13].

Before the DMFC test, the methanol concentration was varied from $0.5 \mathrm{M}$ to $2 \mathrm{M}$ keeping the temperature fixed at $30^{\circ} \mathrm{C}$ with $60 \%$ relative humidity of air. Figure $6 \mathrm{~b}$ shows the performance of DMFC for the $1.5 \mathrm{Si}$ PWA/PVA membrane at different methanol concentrations $(0.5$ to $2 \mathrm{M})$. Increase in the methanol concentration from $0.5 \mathrm{M}$ to $2 \mathrm{M}$ increased OCV of the cell from $0.761 \mathrm{~V}$ to $0.813 \mathrm{~V}$, which indicated that the methanol crossover was not prominent even at higher methanol concentration (2 $\mathrm{M})$ as also mentioned in Figure 6a. Peak power density increased from 19.3 $\mathrm{mWcm}^{-2}$ (at cell voltage $0.386 \mathrm{~V}$ ) to $26.2 \mathrm{mWcm}^{-2}$ (at a cell voltage of $0.438 \mathrm{~V}$ ) as methanol concentration was increased from 0.5 to $2 \mathrm{M}$. However, the maximum achieved current density changed little $\left(67 \mathrm{mAcm}^{-2}\right.$ for $0.5 \mathrm{M}$ and $68 \mathrm{mAcm}^{-2}$ for $2 \mathrm{M}$ ) with increase in methanol concentration. On the other hand, poor DMFC performance has been reported for the Nafion117 at this methanol concentration (2 M) [14].

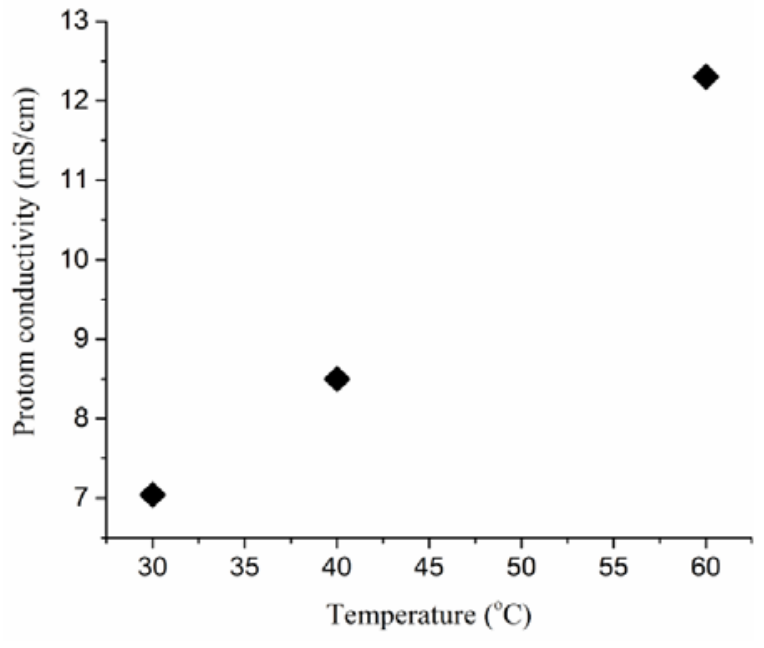

a

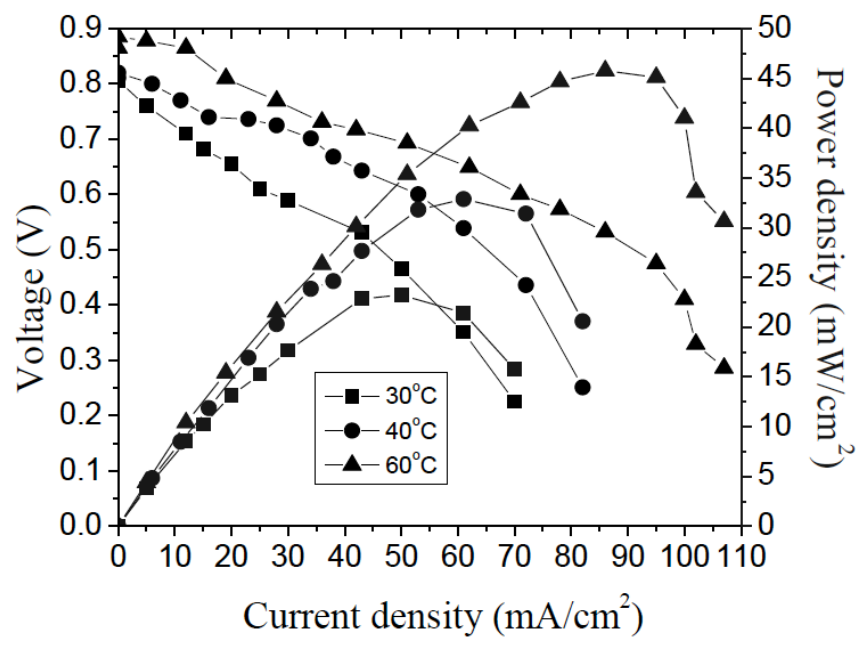

b

Figure 5: Effect of temperature on (a) proton conductivity measured at ambient humidity and (b) DMFC performance for the synthesized composite membrane. 


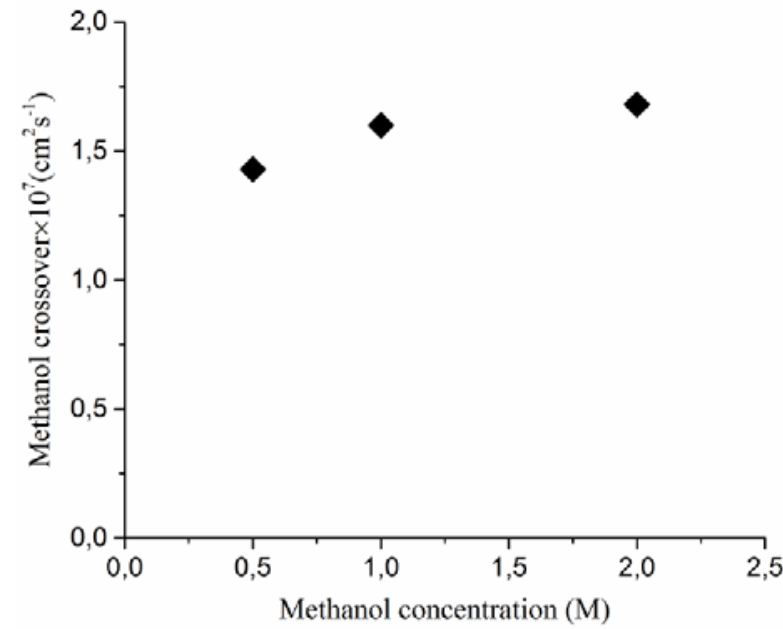

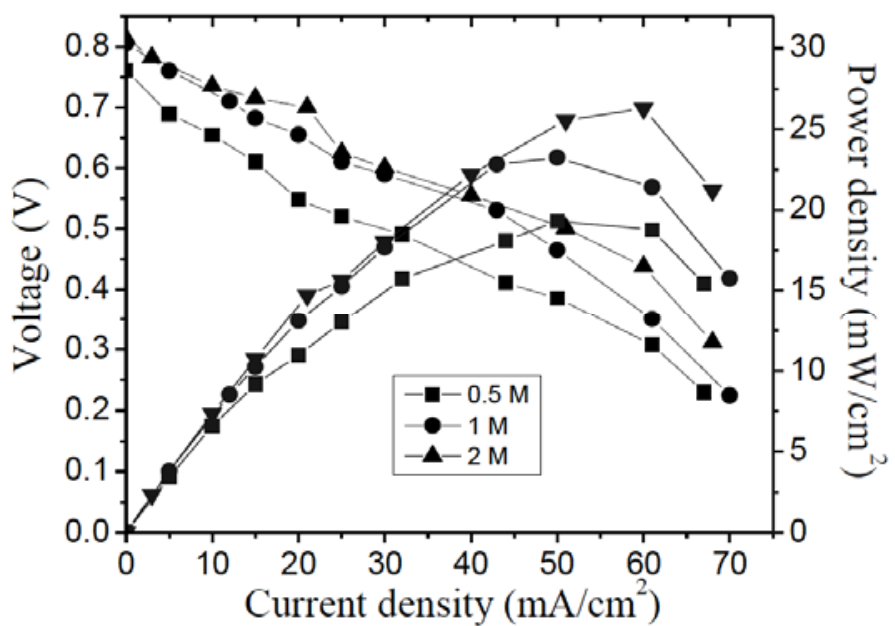

b

Figure 6: Effect of methanol concentration on (a) methanol crossover and (b) DMFC performance for the synthesized composite membrane.

\section{Effect of Relative Humidity}

The proton conductivity of the synthesized $1.5 \mathrm{Si}$ PWA/PVA membrane was also measured at $30^{\circ} \mathrm{C}$ under varying relative humidity before the DMFC test. It was observed that on increasing relative humidity from 40 to $90 \%$ the proton conductivity of the membrane increased from $5.5 \mathrm{mScm}^{-1}$ to $11.5 \mathrm{mScm}^{-1}$ as shown in Figure 7a. Improved proton conductivity was due to better hydration of membrane at higher humidification causing easy conduction of protons through the membrane [15]. The results also indicate that the synthesized membrane has good hydrolytic stability.

For DMFC test, relative humidity of the air was varied from 40 to $90 \%$ keeping the temperature fixed at $30^{\circ} \mathrm{C}$ with methanol concentration $1 \mathrm{M}$. Figure $7 \mathrm{~b}$ shows the performance of DMFC for the $1.5 \mathrm{Si}$ PWA/PVA membrane at different relative humidities 40 to $60 \%$. OCV increased from $0.745 \mathrm{~V}$ for $40 \%$ relative humidity to $0.878 \mathrm{~V}$ at $90 \%$ relative humidity. However, increase in peak power density was small; from 21 $\mathrm{mWcm}^{-2}$ (at cell voltage of $0.419 \mathrm{~V}$ ) at $40 \%$ relative humidity to $26.8 \mathrm{mWcm}^{-2}$ (at a cell voltage of $0.489 \mathrm{~V}$ ) at $90 \%$ relative humidity. The maximum achieved current density at $40 \%$ relative humidity was 69 $\mathrm{mAcm}^{-2}$ and it increased to $73 \mathrm{mAcm}^{-2}$ at $90 \%$ relative humidity. Unlike conventional Nafion membranes, DMFC performance for the synthesized $1.5 \mathrm{Si}$ PWA/PVA membrane did not deteriorated on increasing humidity to $90 \%$ which exhibits good water stability of the membrane. The results have also good

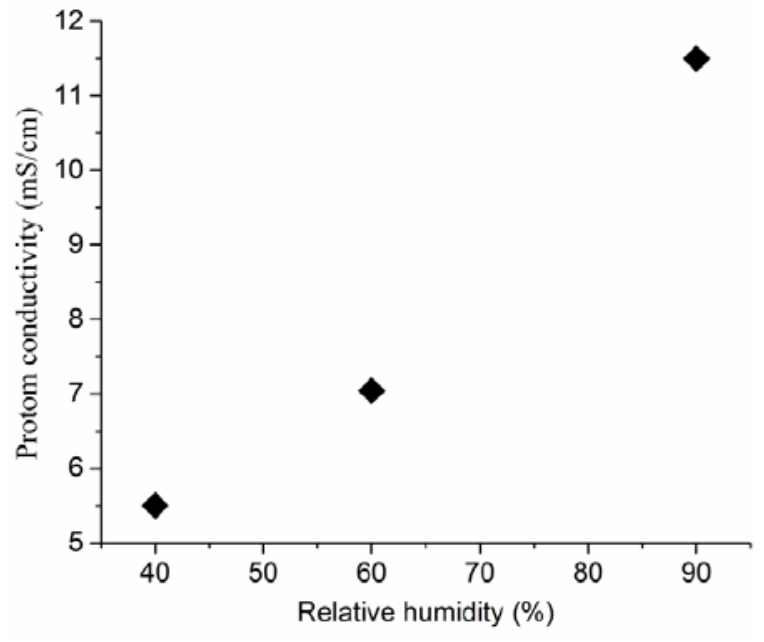

a

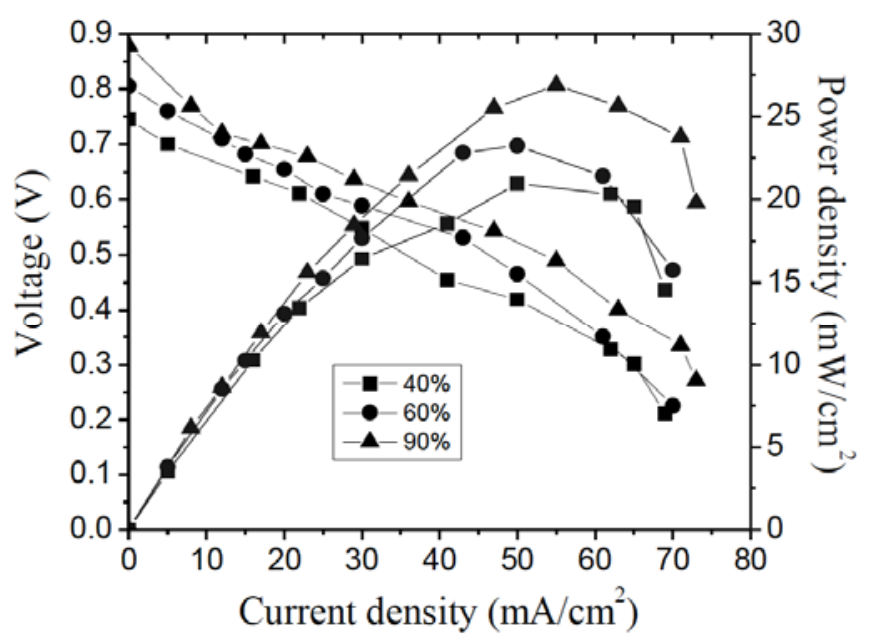

b

Figure 7: Effect of relative humidity on (a) proton conductivity measured at $30^{\circ} \mathrm{C}$ and (b) DMFC performance for the synthesized composite membrane. 
agreement with the proton conductivity of the membrane at higher relative humidity.

\section{CONCLUSIONS}

In summary, operating temperature, methanol concentration and relative humidity have significant effects on single cell DMFC performance. Compared to Nafion-117, much lower OCV decay (1.84\%) was observed for the synthesized membrane due to lower methanol crossover through the PVA matrix having poor selectivity for methanol. The best DMFC performance, in terms of power density, for the synthesized 1.5 Si-PWA/PVA membrane was observed at $60^{\circ} \mathrm{C}$ cell temperature, $2 \mathrm{M}$ methanol concentration and $90 \%$ relative humidity. Maximum achieved current density and power density was $107 \mathrm{mAcm}^{-2}$ and 45.7 $\mathrm{mWcm}^{-2}$ respectively measured at $60^{\circ} \mathrm{C}$ cell temperature. Results show that the optimized $1.5 \mathrm{Si}$ PWA/PVA membrane is a promising candidate for DMFC

\section{REFERENCES}

[1] Kamarudin SK, Achmad F, Daud WRW. Overview on the application of direct methanol fuel cell (DMFC) for portable electronic devices. Int J Hydrogen Energy 2009; 34: 6902-16. http://dx.doi.org/10.1016/j.ijhydene.2009.06.013

[2] Arico AS, Srinivasan S, Antonucci V. DMFCs: from fundamental aspects to technology development. Fuel Cells 2001: 1: 133-61.

http://dx.doi.org/10.1002/1615-6854(200107)1:2<133::AIDFUCE133>3.0.CO;2-5

[3] Smitha B, Sridhar S, Khan AA. Solid polymer electrolyte membranes for fuel cell applications-a review. J Membr Sci 2005; 259: 10-26.

http://dx.doi.org/10.1016/j.memsci.2005.01.035

[4] Wasmus S, Kuver A. Methanol oxidation and direct methanol fuel cells: a selective review. J Electroanal Chem 999; 461: 14-31.

http://dx.doi.org/10.1016/s0022-0728(98)00197-1
[5] Mohan S, Shrestha SOB. Experimental investigation of a passive direct methanol fuel cell. Open Fuel Energy Sci J 2009; 2: 124-28.

http://dx.doi.org/10.2174/1876973X01002010124

[6] Chen S, Ye F, Lin W. Effect of operating conditions on the performance of a direct methanol fuel cell with PtRuMo/CNTs as anode catalyst. Int J Hydrogen Energy 2010; 35: 8225-33. http://dx.doi.org/10.1016/j.ijhydene.2009.12.085

[7] Surampudi S, Narayanan SR, Vamos E, Frank H, Halpert G LaConti A. Advances in direct oxidation methanol fuel cells. $J$ Power Sources 1994; 47: 377-85. http://dx.doi.org/10.1016/0378-7753(94)87016-0

[8] Yu B, Yang Q, Kianimanesh A, Freiheit T, Park SS, Zhao H Xue D. A CFD model with semi-empirical electrochemical relationships to study the influence of geometric and operating parameters on DMFC performance. Int $\mathrm{J}$ Hydrogen Energy 2013; 38: 9873-85. http://dx.doi.org/10.1016/i.ijhydene.2013.05.118

[9] Oliveira VB, Rangel CM, Pinto AMFR. Performance of a direct methanol fuel cell operating close to room temperature. J Fuel Cell Sci Tech 2011; 8: 1-8. http://dx.doi.org/10.1115/1.4002311

[10] Pandey J, Mir FQ, Shukla A. Synthesis of silica immobilized phosphotungstic acid (Si-PWA)-poly(vinyl alcohol) (PVA) composite ion-exchange membrane for direct methanol fuel cell. Int J Hydrogen Energy 2014; 39: 9473-81. http://dx.doi.org/10.1016/j.ijhydene.2014.03.237

[11] Lu J, Tang H, Lu S, Wu H, Jiang SP. A novel inorganic proton exchange membrane based on self-assembled HPWmeso-silica for direct methanol fuel cells. J Mater Chem 2011; $21: 6668-76$ http://dx.doi.org/10.1039/c0jm03695a

[12] Pandey J, Mir FQ, Shukla A. Performance of PVDF supported silica immobilized phosphotungstic acid membrane (Si-PWA/PVDF) in direct methanol fuel cell. Int $J$ Hydrogen Energy 2014; 39: 17306-13. http://dx.doi.org/10.1016/j.ijhydene.2014.08.046

[13] Deluca NW, Elabd YA. Direct methanol fuel cell performance of Nafion $\AA /$ poly (vinyl alcohol) blend membranes. J Power Sources 2006; 163: 386-91. http://dx.doi.org/10.1016/j.jpowsour.2006.09.009

[14] Scott K, Taama WM, Argyropoulos P, Sundmacher K. The impact of mass transport and methanol crossover on the direct methanol fuel cell. J Power Source 1999; 83: 204-16. http://dx.doi.org/10.1016/S0378-7753(99)00303-1

[15] Zawodzinski TA, Springer TE, Uribe F, Gottesfeld S. Characterization of polymer electrolytes for fuel cell applications. Solid State Ionics 1993; 60: 199-211. http://dx.doi.org/10.1016/0167-2738(93)90295-E 